\title{
Influence of temperature on growth, toxicity and carbohydrate production of a Japanese Ostreopsis ovata strain, a toxic-bloom-forming dinoflagellate
}

\author{
Nayani K. Vidyarathna*, Edna Granéli \\ School of Natural Sciences, Marine Ecology Department, Linnaeus University, Kalmar 39182, Sweden
}

\begin{abstract}
Ostreopsis ovata is a benthic dinoflagellate that produces palytoxin and its analogues. Since the end of the 1990s, toxic blooms of O. ovata have been recorded in many tropical and temperate marine waters. These blooms often kill benthic invertebrates and cause health problems for humans. We hypothesize that increases in seawater temperature might induce these blooms. A strain of $O$. ovata isolated from the southern coast of Japan was selected for study. $O$. ovata cells were exposed to 7 different temperatures from 24 to $30^{\circ} \mathrm{C}$ for $30 \mathrm{~d}$, and growth rates were noted. The specific growth rate was found to be highest at $25^{\circ} \mathrm{C}$, next highest at $24^{\circ} \mathrm{C}$ and lower at $26,28,27,30$ and $29^{\circ} \mathrm{C}$, in that order. The hypothesis that increased seawater temperature causes increases in growth rate was thus not supported. The cell toxicity and carbohydrate production of $O$. ovata were highest at the temperature range that is optimal for cell growth. Increasesing sea surface temperature, as a result of global warming, is therefore not likely to have a substantial effect on the bloom formation and toxicity of this Japanese strain of O. ovata.
\end{abstract}

KEY WORDS: Ostreopsis ovata - Benthic dinoflagellate $\cdot$ Palytoxin · Toxicity $\cdot$ Climate change · Carbohydrate production

Resale or republication not permitted without written consent of the publisher

\section{INTRODUCTION}

Over the past few decades, harmful algal bloom (HAB) incidents have increased in frequency, intensity and geographical extent (Hallegraeff 2003, Glibert et al. 2005). Anthropogenic activities are considered to contribute to this increase in HABs (Glibert et al. 2005). Nutrient enrichment, overfishing, agriculture and aquaculture practices, the introduction of toxic species via ballast water dispersion or shellfish transplantation and climate changes increase HABs (Hallegraeff 2003, Glibert et al. 2005).

The Intergovernmental Panel on Climate Change (IPCC) predicts an increase in world average atmospheric temperatures of 1.8 to $4^{\circ} \mathrm{C}$ over the 21st century (IPCC 2007). Increases of sea surface temperature (SST), acidification, change in the stratification of water masses, precipitation and the timing and volume of freshwater runoff are impacts on marine ecosystems (IPCC 2007). These factors can have direct or indirect effects on phytoplankton growth. Climate change may therefore influence the formation and geographical expansion of HABs (Glibert et al. 2005, Dale et al. 2006).

Elevated seawater temperatures may favour the dominance of warm-water harmful algae species in the phytoplankton community and the extension of their range to higher latitudes (Tester et al. 2010). This is also evidenced by the expansion and the occurrence of the tropical benthic dinoflagellate Ostreopsis ovata in temperate regions (Totti et al. 2010, Pistocchi et al. 2011).

Ostreopsis ovata Fukuyo is found epiphytic on red and brown macroalgae and can also grow on other benthic substrata, such as rocks, soft sediments and benthic invertebrates (Fukuyo 1981, Faust et al. 1996, Granéli et al. 2002, Totti et al. 2010). O. ovata was found to be an important component in temper- 
ate marine waters (Vila et al. 2001, Adachi et al. 2008, Shears \& Ross 2009). O. ovata produces palytoxin and its analogues, such as ovatoxin-a, b, c and d (Ciminiello et al. 2010). Toxins produced by Ostreopsis spp. cause human fatalities - as the toxins accumulate higher up in marine food webs (fishes) - and mortality of benthic invertebrates, such as sea urchins (Granéli et al. 2002, Taniyama et al. 2003, Durando et al. 2007, Shears \& Ross 2009).

Ostreopsis ovata produces copious amounts of mucilage (Granéli et al. 2002, Guerrini et al. 2010, Totti et al. 2010). A mucilaginous matrix helps $O$. ovata cells attach themselves to the substrate (Granéli et al. 2002, Totti et al. 2010). Mucilaginous mats adhere loosely to the substrata so that the mat can easily be resuspended in the water column by wave and mechanical action (Totti et al. 2010). Blooms of $O$. ovata are often associated with thick mucilaginous mats, which can have an ecological impact, thus their bloom expansion is of great concern (Granéli et al. 2002 and 2011). The determination of the effects of temperature increases on the growth, toxicity and carbohydrate production of $O$. ovata is of major interest.

Temperature regulates the growth and toxicity of Ostreopsis ovata (Granéli et al. 2002, 2011, Pistocchi et al. 2011). Some studies show that Ostreopsis spp. blooms coincide with increasing temperature, $>25^{\circ} \mathrm{C}$ (e.g. Pistocchi et al. 2011). Other studies show that seawater temperature is not a primary driver of Ostreopsis spp. proliferation (Totti et al. 2010, Mangialajo et al. 2011). This suggests that the relationship between temperature and the growth and/or toxicity of $O$. ovata might differ among strains.

In this work, we investigated the effect of temperature on the growth, toxicity and carbohydrate production of a Japanese strain of Ostreopsis ovata.

\section{MATERIALS AND METHODS}

Ostreopsis ovata strain s0662 was obtained from the Laboratory of Aquatic Environmental Science, Department of Aquaculture, Kochi University, Japan.

\section{Experimental set-up}

Prior to commencement of the experiment, Ostreopsis ovata cells were grown in $\mathrm{f} / 10$ medium (Guillard \& Ryther 1962) at $25^{\circ} \mathrm{C}$, with a light irradiation of $140 \mu \mathrm{mol}$ photons $\mathrm{m}^{-2} \mathrm{~s}^{-1}$ by cool-white Osram tubes and exposed to a 12:12 h light:dark cycle. The culture medium was prepared with filtered and autoclaved Skagerrack seawater (salinity $31 \mathrm{psu}$ ). Initial culture volumes of $225 \mathrm{ml}$ were exposed to $24,25,26,27,28$, 29 and $30^{\circ} \mathrm{C}$, which varied in the range of $\pm 0.3^{\circ} \mathrm{C}$ (Fig. 1).

Chlorophyll a was determined fluorometrically (Turner Designs 10-AU) after filtration of sub-samples (5 to $10 \mathrm{ml}$ ) through Whatman GF/C $(25 \mathrm{~mm})$ glass microfibre filters and ethanol extraction of the filter for $2 \mathrm{~h}$ in the dark at room temperature (Jespersen \& Christoffersen 1987). When the cultures reached stationary phase, chlorophyll a levels were analysed daily. The samples for cell counts were preserved with acidic Lugol's solution, settled in a Palmer-Maloney counting chamber $(0.1 \mathrm{ml})$ and were manually counted on an inverted microscope (Olympus CKX 41 ) at 200× magnification (Palmer \& Maloney 1954).

Samples for toxin analyses (15 to $25 \mathrm{ml}$ ) and for analyses of particulate and dissolved carbohydrate concentrations $(2 \mathrm{ml})$ were drawn from each replicate on Day 10, 16, 24 or 26, corresponding to the early and mid-exponential and mid-stationary phases based on chlorophyll a growth curves. The cultures were manually well mixed before each sampling to homogenize the samples.

The experiment was terminated after the growth curves entered the decaying phase with the final harvest at Day 30. The specific growth rate $(\mu)$ of each treatment was calculated during the exponential growth phases using the following formula:

$$
\mu=\left(\ln N_{2}-\ln N_{1}\right) /\left(t_{2}-t_{1}\right)
$$

where $N_{1}$ and $N_{2}$ are cell densities at time $t_{1}$ and $t_{2}$.

Inorganic nitrogen $\left(\mathrm{NO}_{3}{ }^{-}\right)$and phosphorus $\left(\mathrm{PO}_{4}{ }^{3-}\right)$ analyses were performed during the stationary and

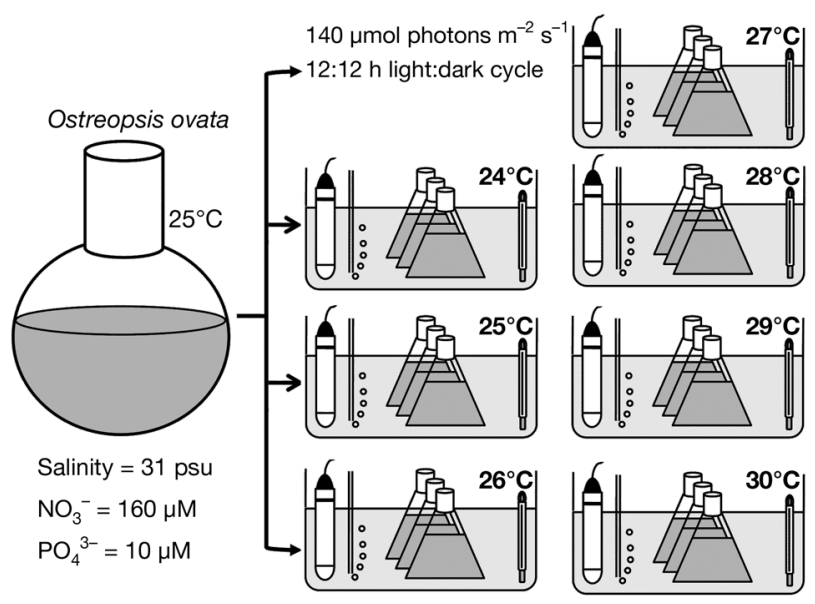

Fig. 1. Experimental set-up used to grow Ostreopsis ovata at constant temperatures $\left(24,25,26,27,28,29\right.$ and $\left.30^{\circ} \mathrm{C}\right)$ 
decaying phases using the standard methods for seawater analyses (Valderama 1995).

\section{Haemolytic activity}

Sub-samples were filtered onto Whatman GF/C (25 mm) $1.2 \mu \mathrm{m}$ mesh size glass microfibre filters and were stored at $-20^{\circ} \mathrm{C}$ prior to analysis. The cells retained on the filters were extracted in $1.5 \mathrm{ml}$ of methanol for $30 \mathrm{~min}$ in the dark. The filtrates of these samples were tested for toxicity as well.

Measurement of the haemolytic activity of Ostreopsis ovata cells was based on the method of Igarashi et al. (1998) and Stolte et al. (2002), with some modifications. Briefly, O. ovata cells methanolic extracts and cell-free medium were mixed in different ratios (4 to $50 \%$ of extracts or 8 to $100 \%$ of filtrates) with isotonic phosphate buffer (IPB) in 96-well micro plates (total volume $50 \mu \mathrm{l}$ ), after which $200 \mu \mathrm{l}$ of $1 \%$ horse blood cell suspension in IPB was added and incubated for $4 \mathrm{~h}$. Saponin (Sigma S-2149) in IPB (0 to $48 \%$ ) was used to produce a standard haemolytic curve as the reference. The haemolytic activity was measured as absorbance at $405 \mathrm{~nm}$ with a microplate reader (FLUOstar OPTIMA, BMG LABTECH). The methanol haemolytic activity, at the volumes used in the test for the cell extracts, was also determined, to check the possible toxic effect of methanol that could be interpreted as the toxin itself. All the tests were performed in duplicate.

The haemolytic activity of Ostreopsis ovata cells was calculated relative to saponin haemolytic activity and expressed as ng saponin equivalent per cell ( $\mathrm{SnE}$ cell $^{-1}$ ). The $\mathrm{HE}_{50}$ of methanolic O. ovata cell extracts (the equivalent cell concentration that causes $50 \%$ haemolysis of a horse red blood cell standard) was determined by a linear fit between the log of O. ovata cell concentration in each dilution vs. the percentage of haemolysis. A linear fit ( $\%$ haemolysis $=a+b x \log$ cell concentration) was made in Excel and solved for the percentage of haemolysis $=50$. The $\mathrm{HE}_{50}$ of the saponin dilution series was determined in the same way. The haemolytic activity of $O$. ovata as $\mathrm{SnE}$ cell $^{-1}$ was then calculated by dividing the $\mathrm{HE}_{50}$ of the saponin series $\left(\mathrm{ng} \mathrm{ml}^{-1}\right)$ by the $\mathrm{HE}_{50}$ of the O. ovata methanolic extract (equivalent cell $\mathrm{ml}^{-1}$ ).

\section{Carbohydrate analysis}

Aliquots of $2 \mathrm{ml}$ of Ostreopsis ovata cultures from each replicate were transferred to Eppendorf tubes and centrifuged for $10 \mathrm{~min}$ at $10000 \times g$ (Eppendorf $5417 \mathrm{C})$. The supernatants were transferred to clean Eppendorf tubes without disturbing the cell pellets. Both the cell pellets and supernatants were stored at $-20^{\circ} \mathrm{C}$ until analysis.

The cell pellets, after adding $1.2 \mathrm{ml}$ of $1 \mathrm{M} \mathrm{H}_{2} \mathrm{SO}_{4}$, were incubated for $1 \mathrm{~h}$ in a boiling water bath and thereafter centrifuged for $5 \mathrm{~min}$ at $300 \times g$ (Eppendorf $5417 \mathrm{C}$ ). The total carbohydrate content in the solution (particulate carbohydrates) was determined by the phenol-sulphuric method using D-(+)-glucose as a standard (DuBois et al. 1956). The cell-free medium, without further preparation, was tested for dissolved carbohydrate (DuBois et al. 1956).

Particulate and dissolved carbohydrate concentrations were expressed as ng of D (+) glucose equivalent per cell. The term 'particulate carbohydrates' in our experiment collectively include both intra- and the extra-cellular carbohydrates that aggregate to form the mucilaginous matrix.

\section{Statistical analyses}

Statistical analysis were performed with GraphPad PRISM using analysis of variance (ANOVA) and Tukey's pairwise comparison test to determine the significance of the differences observed for the maximum growth rates, maximum biomass accumulations and toxin levels per cell among the different temperatures. The differences in particulate and dissolved carbohydrate concentrations between the different growth phases in each treatment were statistically compared using repeated-measures 2-way ANOVA.

\section{RESULTS}

\section{Growth rates, biomass accumulation and inorganic nutrient concentrations}

The biomass of Ostreopsis ovata, expressed as chlorophyll $a$, increased at all the tested temperatures (Fig. 2). Chlorophyll maxima were reached between Days 19 and 27 at all temperatures (Fig. 2). High chlorophyll a values were found at 24 to $25^{\circ} \mathrm{C}$ $\left(186 \pm 1.84\right.$ and $182 \pm 11.6 \mu \mathrm{g} \mathrm{l}^{-1}$, respectively). The lowest values $\left(<174 \mathrm{\mu g} \mathrm{l}^{-1}\right)$ were found above $26^{\circ} \mathrm{C}$ (Fig. 2). When biomass is expressed as cell numbers, the maximum cell densities $\left(4.0 \pm 0.06 \times 10^{3}\right.$ cells $\mathrm{ml}^{-1}$ ) were found at $26^{\circ} \mathrm{C}$ and the lowest cell numbers at $30^{\circ} \mathrm{C}\left(2.8 \pm 0.1 \times 10^{3} \mathrm{cells} \mathrm{ml}^{-1}\right)$ (Fig. 3). Maximum specific growth rates $(\mu)$ based on cell densities were 


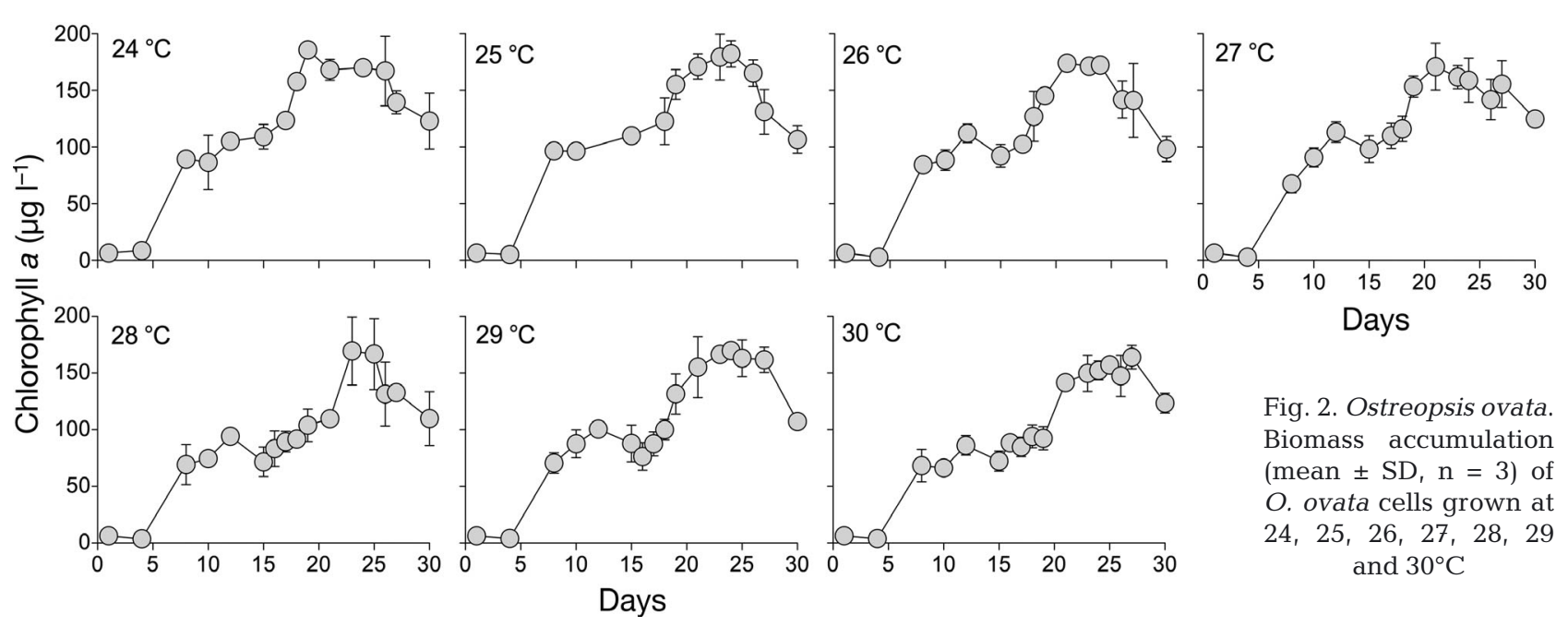

found between Days 4 and 10 (early exponential phase) for all cultures. The highest growth rates were recorded at 25 and $24^{\circ} \mathrm{C}$ (Fig. 3). The lowest growth rates, $0.22 \pm 0.01$ and $0.23 \pm 0.1 \mathrm{~d}^{-1}$, were observed at 29 and $30^{\circ} \mathrm{C}$, respectively.

At the termination of the experiment, the $\mathrm{NO}_{3}{ }^{-}$ and $\mathrm{PO}_{4}{ }^{3-}$ concentrations in the cultures were in the ranges of 0.57 to $0.83 \mu \mathrm{M}$ and 1.23 to $2.40 \mu \mathrm{M}$, respectively.

\section{Haemolytic activity}

Haemolytic activity was only found during the decaying phases for all temperatures. The activity varied in each treatment.

The highest cell toxicities were found in the cultures that grew at $25^{\circ} \mathrm{C}\left(0.70 \pm 0.15 \mathrm{SnE} \mathrm{cell}{ }^{-1}\right)$. The next highest were found at 29 and $24^{\circ} \mathrm{C}(0.64 \pm 0.03$ and $0.62 \pm 0.22 \mathrm{SnE} \mathrm{cell}^{-1}$, respectively). The lowest toxicities, $0.46 \pm 0.01 \mathrm{SnE}$ cell ${ }^{-1}$ were found at $27^{\circ} \mathrm{C}$ (Fig. 4). Toxin levels at lower temperatures (24 to $25^{\circ} \mathrm{C}$ ) were higher. However, no statistically significant differences were found among the treatments (ANOVA, $p>0.05)$. In the filtrates, the toxicity levels were below analytical detection.

\section{Particulate and dissolved carbohydrate concentrations}

Particulate carbohydrate concentrations were statistically significantly higher during the stationary and decaying phases, compared to the exponential phase (repeated-measures 2-way ANOVA, p < 0.0001). Until Day 10, carbohydrate concentrations

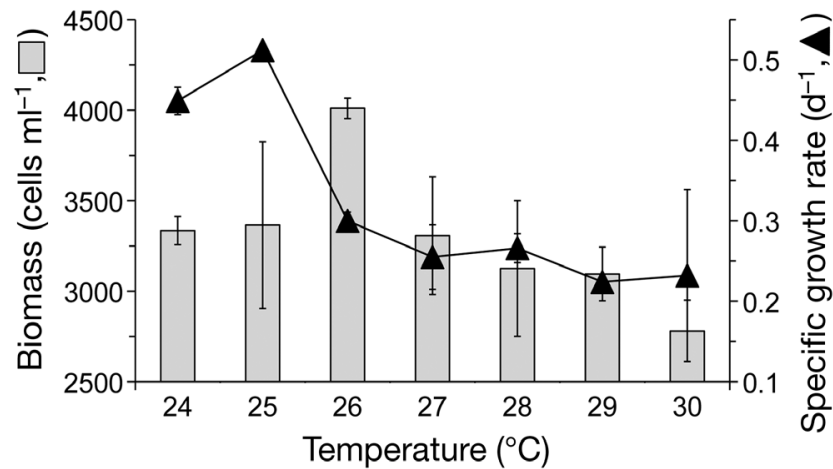

Fig. 3. Ostreopsis ovata. Maximum biomass levels (mean \pm $\mathrm{SD}, \mathrm{n}=3$ ) and maximum specific growth rates (mean $\pm \mathrm{SD}$, $\mathrm{n}=3$ ) of $O$. ovata cultures grown at 24, 25, 26, 27, 28, 29 and $30^{\circ} \mathrm{C}$

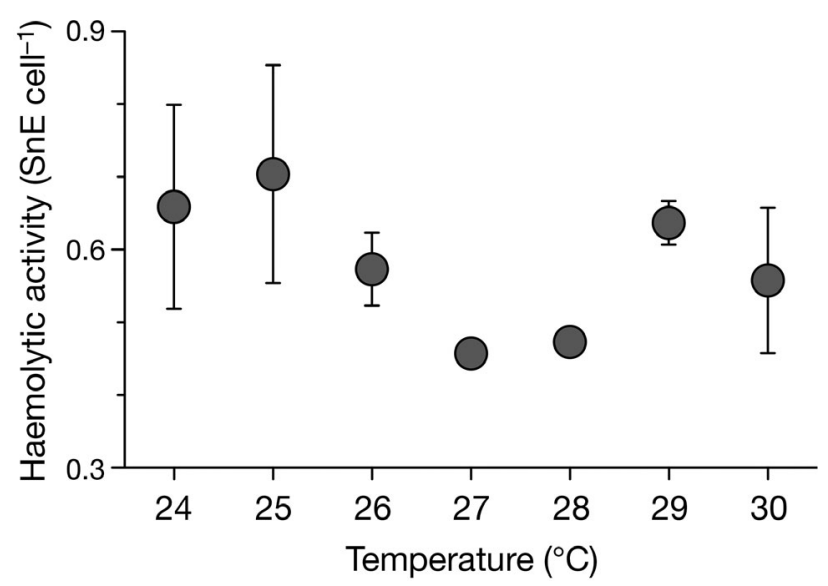

Fig. 4. Ostreopsis ovata. Haemolytic activity (HA) as saponin equivalents (SnE) (mean $\pm \mathrm{SD}, \mathrm{n}=3$ ) of $O$. ovata cells grown at $24,25,26,27,28,29$ and $30^{\circ} \mathrm{C}$ during the decaying phase. During the exponential and stationary phases, HA levels were below analytical detection 
were under analytical detection levels in all cultures. The lowest carbohydrate levels were recorded during the mid-exponential phase in all treatments. The carbohydrate concentrations during the mid-exponential phase remained at comparatively low levels ( 0.15 to $0.56 \mathrm{ng} \mathrm{cell}^{-1}$ ). Slightly higher concentrations were found at higher temperatures (Fig. 5a). During the stationary and decaying phases, the highest carbohydrate concentrations were found at lower temperatures $\left(24\right.$ to $\left.25^{\circ} \mathrm{C}\right)$ and the lowest concentration at higher temperatures (repeated-measures 2-way ANOVA, $\mathrm{p}<0.0001$ ). The maximum particulate carbohydrate levels found in this study ranged between 1.0 to $1.9 \mathrm{ng} \mathrm{cell}^{-1}$, and the lowest were $\sim 0.30 \mathrm{ng}$ cell $^{-1}$ (Fig. 5a).

Except in the early exponential phase, the dissolved carbohydrate concentrations of all the harvests were detectable. However, in no instance did

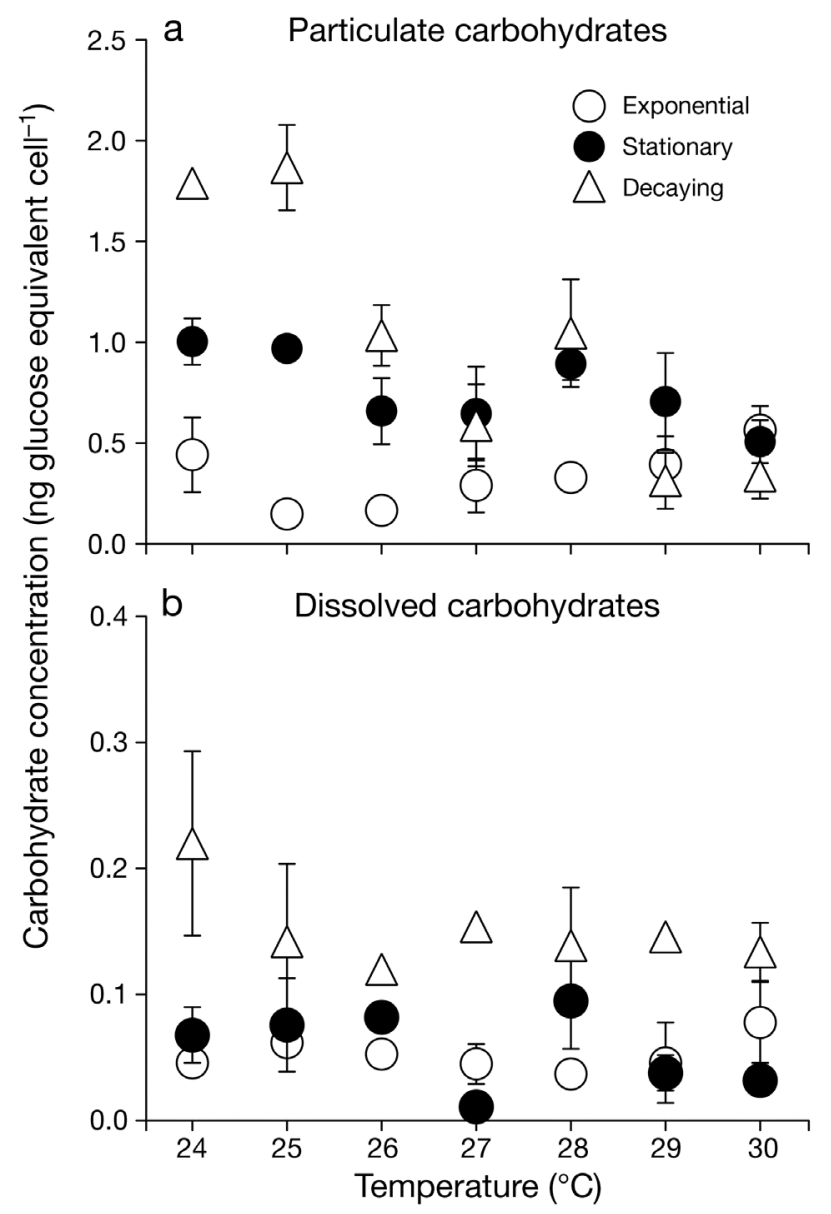

Fig. 5. Ostreopsis ovata. (a) Particulate carbohydrate concentrations and (b) dissolved carbohydrate concentration on a per cell basis (mean $\pm \mathrm{SD}, \mathrm{n}=3$ ) of $O$. ovata cultures in exponential, stationary and decaying phases, grown at 24, 25, $26,27,28,29$ and $30^{\circ} \mathrm{C}$ the levels exceed $0.37 \mu \mathrm{g} \mathrm{ml}^{-1}$, which is equivalent to $0.2 \mathrm{ng} \mathrm{cell}{ }^{-1}$. Significantly higher concentrations were found only in the decaying phase compared to the exponential and stationary phases, for all treatments (repeated-measures 2-way ANOVA, p < 0.01), but no statistically significant differences were found among the temperature treatments (Fig. 5b).

\section{DISCUSSION}

The growth rate of Ostreopsis ovata increased over the range of 24 to $25^{\circ} \mathrm{C}$ and declined from 26 to $30^{\circ} \mathrm{C}$. The maximum stationary biomass levels were recorded at $26^{\circ} \mathrm{C}$. Haemolytic activity was only detectable during the decaying phase. O. ovata showed the highest toxicity at $25^{\circ} \mathrm{C}$ and the lowest toxicity from 27 to $28^{\circ} \mathrm{C}$. Significantly higher particulate carbohydrate concentrations were found in the stationary and decaying phases of the cultures at 24 to $25^{\circ} \mathrm{C}$.

In this study, we found that both the toxicity and carbohydrate production of $O$. ovata were higher at the temperatures of 24 to $25^{\circ} \mathrm{C}$, which are optimal for cell growth.

\section{Cell growth and biomass accumulation}

Ostreopsis spp. occur in high cell densities during warmer periods (Pistocchi et al. 2011 and references therein). We found that $O$. ovata show a typical growth at 24 to $30^{\circ} \mathrm{C}$, with the optimum at 24 to $25^{\circ} \mathrm{C}$. In Tei port, on the Southern Japanese coast, where our O. ovata strain originated, Ostreopsis spp. occur over a wide temperature range, 15 to $30^{\circ} \mathrm{C}$, and with high cell densities $\left(\sim 1000\right.$ cells $\mathrm{g}^{-1}$ macroalgae) above $25^{\circ} \mathrm{C}$ (Adachi et al. 2008, M. Adachi pers. comm.). We found the maximum $O$. ovata biomass at $26^{\circ} \mathrm{C}$. Growth rates at $24^{\circ} \mathrm{C}$ were also high, which indicated that the lower thermal threshold might be below $24^{\circ} \mathrm{C}$. $O$. ovata might therefore thrive at temperatures below those we tested.

Different species or strains in different environments demonstrate different optimum growth temperatures. For instance, a Tyrrhenian Ostreopsis ovata strain showed optimal growth at 26 to $30^{\circ} \mathrm{C}$, whereas an Adriatic strain showed optimal growth at $20^{\circ} \mathrm{C}$ (Pistocchi et al. 2010, Granéli et al. 2011). In line with our findings, 2 tropical strains of Ostreopsis siamensis and $O$. heptagona had maximum growth rates at $25^{\circ} \mathrm{C}$, and the rates decreased with higher temperatures (Fig. 6) (Morton et al. 1992). 


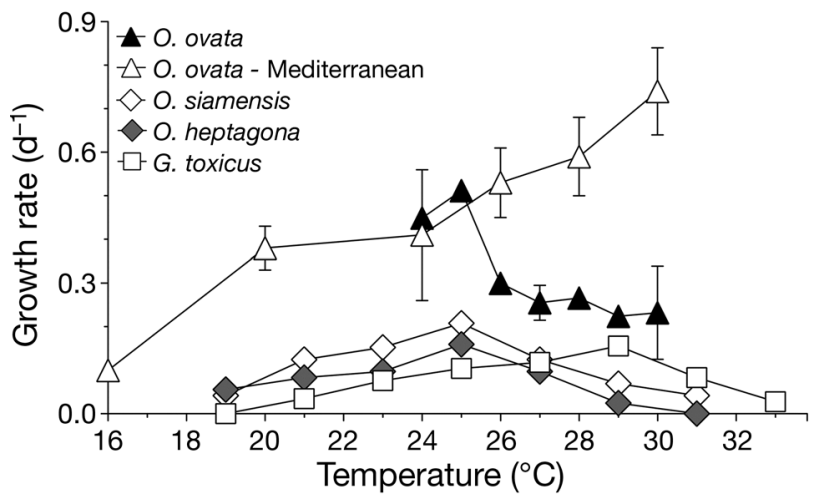

Fig. 6. Maximum growth rates of Ostreopsis ovata at 24 to $30^{\circ} \mathrm{C}$. For comparison, O. ovata Mediterranean strain at 16 to $30^{\circ} \mathrm{C}$ (Granéli et al. 2011), Ostreopsis siamensis at 19 to $31^{\circ} \mathrm{C}$, Ostreopsis heptagona at 19 to $31^{\circ} \mathrm{C}$ and Gambierdiscus toxicus at 19 to $33^{\circ} \mathrm{C}$ (Morton et al. 1992) are shown

The growth rates of several dinoflagellate species, e.g. Gambierdiscus toxicus, Amphidinium carterae and Coolia monotis, show correlations with increased temperature (Tomas et al. 1989, Morton et al. 1992). Granéli et al. (2011) found, for a Mediterranean Ostreopsis ovata strain, a linear increase of maximum growth rates with a slope of $\sim 0.04^{\circ} \mathrm{d}^{-1} \mathrm{C}^{-1}$ in relation to temperature increases from 16 to $30^{\circ} \mathrm{C}$. No such correlation was found for O. ovata in this study. In comparison, higher temperatures, 27 to $30^{\circ} \mathrm{C}$, increased the growth of the Mediterranean strain (Granéli et al. 2011), while we found a decrease in the growth of O. ovata from Japan.

Temperature is an important factor in defining the biogeographic boundaries within which a species can live (Dale et al. 2006). Therefore, different strains of the same species can be expected to have different optimal temperatures for growth. This may be attributed to genetic adaptations to local environmental conditions, and this adaptation may explain why the growth of different strains of Ostreopsis ovata can have such differing temperature optima.

\section{Cell toxicity}

Cell toxicity, measured as haemolytic activity, of Ostreopsis ovata was highest during the decaying phase. This is in accordance with many studies of phytoplankton species that produce toxins, i.e. that toxicity per cell is highest during the stationary and decaying phases (Granéli \& Flynn 2006, Guerrini et al. 2010, Granéli et al. 2011).

High algal cellular toxicity levels are usually associated with stress caused under unfavourable condi- tions for algal growth (Ogata et al. 1989, Johansson \& Granéli 1999, Ashton et al. 2003, Gedaria et al. 2007). The toxicity of other phytoplankton species has been found to inversely correlate with growth rates (Ogata et al. 1989, Ono et al. 2000, Gedaria et al. 2007). A similar relationship, i.e. a significant increase in cell toxicity as specific growth rates decreased as a result of temperature conditions that are not optimal, has been found in a Mediterranean Ostreopsis ovata strain (Granéli et al. 2011). We found only a slight increase in toxicity at low temperatures $\left(24\right.$ to $\left.25^{\circ} \mathrm{C}\right)$, which, however, was not statistically significant. This implies that temperature increases may not have any impact on cell toxicity of the strain from Japan, as opposed to the Mediterranean strain studied by Granéli et al. (2011).

The haemolytic potency of toxins produced by Ostreopsis spp. is usually lower than that of other toxic phytoplankton species, such as Prymnesium parvum, Amphidinium carteri, A. klebsii and Gambierdiscus toxicus (Nakajima et al. 1981, Yasumoto et al. 1987, Johansson \& Granéli 1999). For example, the haemolytic activity (HA) of toxins produced by $A$. klebsii and G. toxicus were found to be around 6.6 and $29 \mathrm{SnE} \mathrm{cell}{ }^{-1}$ respectively (Nakajima et al. 1981), while $P$. parvum can have toxin levels as high as $42 \mathrm{SnE}$ cell $^{-1}$ under favourable conditions and as high as 257 to $288 \mathrm{SnE}$ cell $^{-1}$ under $\mathrm{N}$ or $\mathrm{P}$ limitation (Johansson \& Granéli 1999). The low HA of Ostreopsis toxins may be attributed to delayed haemolysis, which occurs with palytoxin and its analogues (Habermann et al. 1981).

Variations of toxin production occur among different species as well as different strains. The genus Ostreopsis also exhibits strain variance in toxin production (Rhodes et al. 2010), as do many other phytoplankton species, such as Alexandrium tamarense (Ogata et al. 1987) and Gambierdiscus toxicus (Bomber et al. 1989). Guerrini et al. (2010) found that, under the same environmental conditions, an Adriatic strain of $O$. ovata produces less palytoxins on a biovolume basis than a Tyrrhenian strain. Rhodes et al. (2010) found different toxicity levels for Ostreopsis siamensis strains isolated from New Zealand.

We found that the Japanese strain was less toxic than the Mediterranean strain at 24 to $26^{\circ} \mathrm{C}$ (Fig. 7) (Granéli et al. 2011). The most toxic Ostreopsis ovata strain described in the literature is from Brazilian waters, while the Japanese strain is the least toxic. A lack of toxicity and low levels of toxicity were found in strains of $O$. ovata isolated from Okinawa, the Cook Islands and the Virgin Islands (Nakajima et al. 1981, Tindall et al. 1990, Rhodes et al. 2010). The tox- 


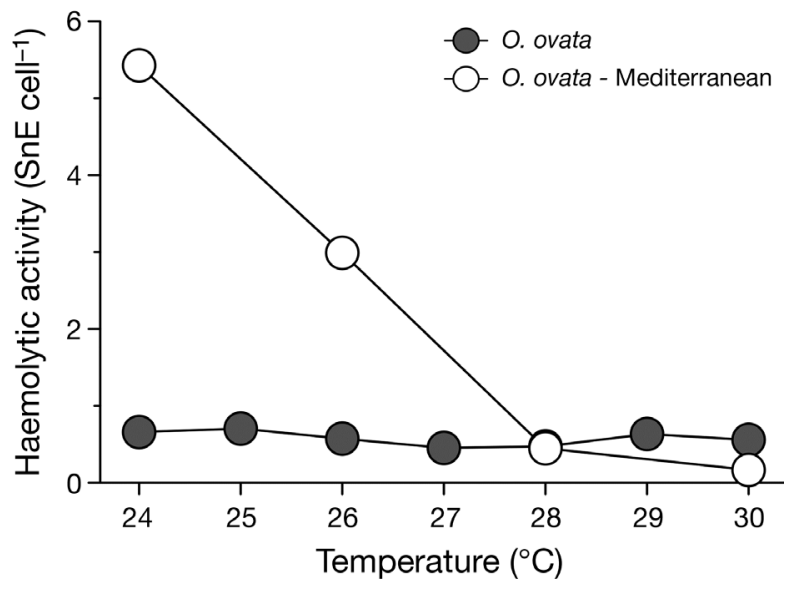

Fig. 7. Ostreopsis ovata. Haemolytic activity of $O$. ovata cells in the present study and from a Mediterranean strain (Granéli et al. 2011) grown at 24 to $30^{\circ} \mathrm{C}$

icity of O. ovata isolated from Okinawa was 80 saponin units per $10^{8}$ cells, or $0.8 \mathrm{SnE} \mathrm{cell}{ }^{-1}$, at $25^{\circ} \mathrm{C}$ (Nakajima et al. 1981), which lies within the range of toxicities found for the strain used in our study.

Toxin production in phytoplankton can be regulated both by intrinsic and extrinsic factors (Granéli \& Flynn 2006). A clear genetic distinction was found between the Atlantic/Mediterranean and the IndoPacific isolates of Ostreopsis ovata (Penna et al. 2010). This is surely related to not only the structural and genetic diversity but also the toxin profiles among different O. ovata strains.

\section{Carbohydrate production}

Our results indicated that actively growing Ostreopsis ovata cultures did not accumulate carbohydrates at any temperature. However, accumulation was evident in the stationary and decaying phases. The higher values we found for O. ovata (1.0 to $\left.1.9 \mathrm{ng} \mathrm{cell}{ }^{-1}\right)$ at lower temperatures $\left(24\right.$ to $\left.26^{\circ} \mathrm{C}\right)$ are of the same order as those found for the benthic dinoflagellate Prorocentrum lima (1.34 ng cell $\left.{ }^{-1}\right)$, grown at $20^{\circ} \mathrm{C}$ (Vanucci et al. 2010). The increase in the production and accumulation of particulate carbohydrates as the growth rates decreased might be due to the increase in release of extracellular carbohydrates rather than an increase in the internal pool of carbohydrates (Liu \& Buskey 2000). A similar pattern of higher accumulation of carbohydrates during the stationary and decaying phases was also found in some diatoms and marine flagellates (Guillard \& Wangersky 1958, Guerrini et al. 1998, Liu \& Buskey 2000, Wolfstein \& Stal 2002). Prymnesium parvum cultures accumulated levels of carbohydrate during the stationary phase that were 10 -fold higher than those during the exponential phase (Guillard \& Wangersky 1958). Phytoplankton were found to produce more polysaccharides when no nitrate and phosphate were left in the medium but when carbon was still available for photosynthesis (Myklestad 1995). Accumulation of extracellular material occurred in stationary-phase cultures because the cells continued production after growth ceased (Myklestad 1977).

Extracellular polymeric substances (EPS), which are mainly composed of polysaccharides, are the ultimate products of photosynthesis and are excreted within a few hours of their synthesis (Underwood et al. 2004). This process can be affected by several other environmental factors, such as nutrient limitation, salinity, irradiance and temperature (Liu \& Buskey 2000, Wolfstein \& Stal 2002, Vanucci et al. 2010). We found, during stationary and decaying phases, that there was a significant decrease in particulate carbohydrate levels at the higher temperatures. The maximum levels were found at temperatures optimal for growth. Similarly Claquin et al. (2008) found that some diatoms grown at the optimal temperatures produced maximum levels of EPS, which decreased with increasing temperature. The highest EPS production per chlorophyll a unit of Cylindrotheca closterium was not recorded at the optimal growth temperatures $\left(15\right.$ and $\left.25^{\circ} \mathrm{C}\right)$ but at a lower temperature $\left(4^{\circ} \mathrm{C}\right)$ (Wolfstein \& Stal 2002). We found that the particulate carbohydrate levels, normalized to cell numbers, cell biovolume (data not shown) and chlorophyll a content, showed a similar decreasing trend at increasing temperature. Therefore, it is clear that our results were not masked by the high cell biomass recorded at lower temperatures. There seems instead to be a direct effect of low temperature on the enhanced production and accumulation of carbohydrates.

It should also be stressed that the mucilage formed by Ostreopsis ovata cultures might hamper adequate homogenization during sampling. This can possibly affect the individual values, and thus the variations of carbohydrate accumulation found in our study in relation to temperature. However, based on the cell counts and chlorophyll measurements, which only showed small deviation between replicates, we could assume that our cultures were well homogenized. We therefore believe that the variation of carbohydrate accumulation that we found represents the natural variation occurring in $O$. ovata cultures in relation to temperature and/or growth phase. 
Several hypotheses have been proposed to explain the potential benefits of enhanced EPS production by microalgae. These exudates may protect the cells against grazing and adverse environmental conditions, such as desiccation and dehydration (Liu \& Buskey 2000, Underwood et al. 2004). EPS may provide means of motility and dispersion for benthic diatoms and dinoflagellates (Wolfstein \& Stal 2002). EPS was also found to stimulate bacterial nutrient re-mineralisation (Guerrini et al. 1998). For example, the dinoflagellate Gonyaulax spp. and the diatom Cylindrotheca fusiformis have competitive advantages over other phytoplankton species because their gelatinous matrix creates a nutrient-rich environment for them, either by scavenging the nutrients present in the surrounding seawater or by withholding microbes in the matrix that will accelerate nutrient remineralisation (Guerrini et al. 1998, MacKenzie et al. 2002). Producing mucilage may also be beneficial for the growth of Ostreopsis ovata in several ways. The mucilaginous matrix may help O. ovata to aggregate, thus facilitating their movement in the matrix, but may also help O. ovata to attach to the substrate (Bomber et al. 1988, Granéli et al. 2002). Most O. ovata blooms have been reported as consisting of thick layers of gelatinous masses covering seaweeds, corals, rocks and sediments (Granéli et al. 2002, Totti et al. 2010, E. Granéli pers. obs.). Thus, high polysaccharide accumulation represents high algal biomass.

\section{CONCLUSIONS}

The growth and toxicity of the Ostreopsis ovata strain, isolated from Tei Port, Japan, did not show a correlation with the seawater temperatures tested in this experiment $\left(24\right.$ to $\left.30^{\circ} \mathrm{C}\right)$. The optimum growth temperature range was 24 to $25^{\circ} \mathrm{C}$. Higher toxicities were also found at these temperatures. Growth did not increase at temperatures above $28^{\circ} \mathrm{C}$, but there was a slight increase in cell toxicities. Particulate carbohydrate concentrations were significantly higher during the stationary and decaying phases of growth at lower temperatures $\left(24\right.$ to $\left.25^{\circ} \mathrm{C}\right)$. This implies that mucilage production aided $O$. ovata growth.

Our study suggests that the increases in sea surface temperature as a result of global warming may not affect the expansion, occurrence, biomass and cell toxicity of the Ostreopsis ovata Japanese strain to the degree expected for other strains, for example those in the Tyrrhenian Sea.
Acknowledgements. We are most grateful to Prof. Masao Adachi, Kochi University, Japan, for providing the O. ovata strain and for valuable information. We are deeply indebted to Dr. Paulo Salomon for preparing the calculation template for the haemolytic data analysis. This study was financially supported by the SIDA/SAREC (Swedish International Development Cooperation Agency) Marine Sciences Programme of the University of Ruhuna, Sri Lanka, a scholarship to N.K.V. and Linnaeus University. Two anonymous reviewers are thanked for valuable comments on an earlier version of the manuscript.

\section{LITERATURE CITED}

Adachi M, Ikegami T, Yamaguchi H (2008) The genus Ostreopsis in the coastal regions in Tosa Bay, southern part of Japan. Abstracts 13th Int. Conf. on Harmful Algae, Hong Kong, 3-7 Nov 2008, p 1

Ashton M, Tosteson T, Tosteson C (2003) The effect of elevated temperature on the toxicity of the laboratory cultured dinoflagellate Ostreopsis lenticularis (Dinophyceae). Rev Biol Trop 51:1-6

Bomber JW, Morton SL, Babinchak JA, Norris DR, Morton JG (1988) Epiphytic dinoflagellates of drift algaeanother toxigenic community in the ciguatera food chain. Bull Mar Sci 43:204-214

Bomber JW, Tindall DR, Miller DM (1989) Genetic variability in toxin potencies among seventeen clones of Gambierdiscus toxicus (Dinophyceae). J Phycol 25:617-625

Ciminiello P, Dell'Aversano C, Iacovo ED, Fattorusso E and others (2010) Complex palytoxin-like profile of Ostreopsis ovata. Identification of four new ovatoxins by highresolution liquid chromatography/mass spectrometry. Rapid Commun Mass Spectrom 24:2735-2744

Claquin P, Probert I, Lefebvre S, Veron B (2008) Effects of temperature on photosynthetic parameters and TEP production in eight species of marine microalgae. Aquat Microb Ecol 51:1-11

Dale B, Edwards M, Reid PC (2006) Phagotrophy in harmful algae. In: Granéli E, Turner JT (eds) Ecology of harmful algae. Springer, Berlin, p 367-378

> DuBois M, Gilles KA, Hamilton JK, Rebers PA, Smith F (1956) Colorimetric method for determination of sugars and related substances. Anal Chem 28:350-356

- Durando P, Ansaldi F, Oreste P, Moscatelli P and others (2007) Ostreopsis ovata and human health: epidemiological and clinical features of respiratory syndrome outbreaks from a two year syndromic surveillance, 2005-06, in north-west Italy. Euro Surveill 12: E070607.1

Faust MA, Morton SL, Quod JP (1996) Further SEM study of marine dinoflagellates: the genus Ostreopsis (Dinophyceae). J Phycol 32:1053-1065

Fukuyo Y (1981) Taxonomical study on benthic dinoflagellates collected in coral reefs. Bull Jpn Soc Sci Fish 47:967-978

Gedaria AI, Luckas B, Reinhardt K, Azanza RV (2007) Growth response and toxin concentration of cultured Pyrodinium bahamense var. compressum to varying salinity and temperature conditions. Toxicon 50:518-529

Glibert PM, Anderson DM, Gentien P, Graneli E, Sellner KG (2005) The global, complex phenomena of harmful algal blooms. Oceanography 18:130-141

Granéli E, Flynn K (2006) Chemical and physical factors influencing toxin content. In: Granéli E, Turner JT (eds) Ecology of harmful algae. Springer, Berlin, p 229-241 
Granéli E, Ferreira CEL, Yasumoto T, Rodrigues EM, Neves B (2002) Sea urchins poisoning by the benthic dinoflagellate Ostreopsis ovata on the Brazilian Coast. In: Steidinger KA (ed) Book of Abstracts 10th Int Conf on Harmful Algae, St. Pete Beach, FL, 21-25 Oct 2002, p 113

Granéli E, Vidyarathna NK, Funari E, Cumaranatunga PRT, Scenati R (2011) Can increases in temperature stimulate blooms of the toxic benthic dinoflagellate Ostreopsis ovata? Harmful Algae 10:165-172

> Guerrini F, Mazzotti A, Boni L, Pistocchi R (1998) Bacterialalgal interactions in polysaccharide production. Aquat Microb Ecol 15:247-253

- Guerrini F, Pezzolesi L, Feller A, Riccardi M and others (2010) Comparative growth and toxin profile of cultured Ostreopsis ovata from the Tyrrhenian and Adriatic Seas. Toxicon 55:211-220

Guillard RRL, Ryther JH (1962) Studies of marine plankton diatoms. I. Cyclotella nana Hustedt and Detonula confervacea (Cleve) Gran. Can J Microbiol 8:229-239

Guillard RRL, Wangersky PJ (1958) The production of extracellular carbohydrates by some marine flagellates. Limnol Oceanogr 3:449-454

> Habermann E, Ahnert-Hilger G, Chhatwal GS, Beress L (1981) Delayed haemolytic action of palytoxin: general characteristics. Biochim Biophys Acta 649:481-486

Hallegraeff GM (2003) Harmful algal blooms: a global overview. In: Hallegraeff GM, Anderson DM, Cembella $\mathrm{AD}$ (eds) Manual on harmful marine microalgae-Monographs on oceanographic methodology 11. UNESCO, Paris, p 25-50

Igarashi T, Aritake S, Yasumoto T (1998) Biological activities of Prymnesin-2 isolated from a red tide alga Prymnesium parvum. Nat Toxins 6:35-41

IPCC (Intergovernmental Panel on Climate Change) (2007) Climate Change 2007 Synthesis report. Cambridge University Press, New York, NY

Jespersen AM, Christoffersen K (1987) Measurements of chlorophyll-a from phytoplankton using ethanol as extraction solvent. Arch Hydrobiol 109:445-454

> Johansson N, Granéli E (1999) Influence of different nutrient conditions on cell density, chemical composition and toxicity of Prymnesium parvum (Haptophyta) in semicontinuous cultures. J Exp Mar Biol Ecol 239:243-258

Liu H, Buskey EJ (2000) Hypersalinity enhances the production of extracellular polymeric substance (EPS) in the Texas brown tide alga, Aureoumbra lagunensis (Pelagophyceae). J Phycol 36:71-77

MacKenzie L, Sims I, Beuzenberg V, Gillespie P (2002) Mass accumulation of mucilage caused by dinoflagellate polysaccharide exudates in Tasman Bay, New Zealand. Harmful Algae 1:69-83

Mangialajo L, Ganzin N, Accoroni S, Asnaghi V and others (2011) Trends in Ostropsis proliferation along the northern Mediterranean coasts. Toxicon 57:408-420

Morton SL, Norris DR, Bomber JW (1992) Effect of temperature, salinity, and light intensity on the growth and seasonality of toxic dinoflagellates associated with ciguatera. J Exp Mar Biol Ecol 157:79-90

Myklestad S (1977) Production of carbohydrates by marine planktonic diatoms. II. Influence of the N/P ratio in the growth medium on the assimilation ratio, growth rate, and production of cellular and extracellular carbohydrates by Chaetoceros affinis var. willei (Gran) Hustedt and Skeletonema costatum (Grev.) Cleve. J Exp Mar Biol Ecol 29:161-179
Myklestad SM (1995) Release of extracellular products by phytoplankton with special emphasis on polysaccharides. Sci Total Environ 165:155-164

Nakajima I, Oshima Y, Yasumoto T (1981) Toxicity of benthic dinoflagellates in Okinawa. Bull Jpn Soc Sci Fish 47: 1029-1033

> Ogata T, Kodama M, Ishimaru T (1987) Toxin production in the dinoflagellate Protogonyaulax tamarensis. Toxicon 25:923-928

Ogata T, Kodama M, Ishimaru M (1989) Effect of water temperature and light intensity on growth rate and toxin production of toxic dinoflagellates. In: Okaichi T, Anderson DM, Nemoto T (eds) Red tides: biology, environmental science and toxicology. Elsevier, New York, NY, p 423-426

> Ono K, Khan S, Onoue Y (2000) Effects of temperature and light intensity on the growth and toxicity of Heterosigma akashiwo (Raphidophyceae). Aquac Res 31:427-433

Palmer CM, Maloney TE (1954). A new counting slide for nanoplankton. Limnol Oceanogr Soc Amer (Spec Publ) 21:1-6

Penna A, Fraga S, Battocchi C, Casabianca S, Giacobbe MG, Riobó P, Vernesi C (2010) A phylogeographical study of the toxic benthic dinoflagellate genus Ostreopsis Schmidt. J Biogeogr 37:830-841

Pistocchi R, Pezzolesi L, Guerrini F, Vanucci S and others (2010) Influence of the environmental conditions on Ostreopsis ovata growth and toxicity. Abstracts 14th Int Conf on Harmful Algae, Crete, Greece, 1-5 Nov 2010, p 48

> Pistocchi R, Pezzolesi L, Guerrini F, Vanucci S, Dell'Aversano C, Fattorusso E (2011) A review on the effects of environmental conditions on growth and toxin production of Ostreopsis ovata. Toxicon 57:421-428

Rhodes L, Smith K, Munday R, Briggs L, Selwood A, Adamson J, Holland P (2010) Ostreopsis isolates from Rarotonga, Cook Islands. 14th Int Conf on Harmful Algae, Crete, Greece, 1-5 Nov 2010 (poster presentation), p 229

> Shears NT, Ross PM (2009) Blooms of benthic dinoflagellates of the genus Ostreopsis; an increasing and ecologically important phenomenon on temperate reefs in New Zealand and worldwide. Harmful Algae 8:916-925

> Stolte W, Panosso R, Gisselson LA, Granéli E (2002) Utilization efficiency of nitrogen associated with riverine dissolved organic carbon ( $>1 \mathrm{kDa}$ ) by two toxin-producing phytoplankton species. Aquat Microb Ecol 29:97-105

> Taniyama S, Arakawa O, Terada M, Nishio S, Takatani T, Mahmud Y, Noguchi T (2003) Ostreopsis sp., a possible origin of palytoxin (PTX) in parrotfish Scarus ovifrons. Toxicon 42:29-33

> Tester PA, Feldman RL, Nau AW, Kibler SR, Litaker RW (2010) Ciguatera fish poisoning and sea surface temperatures in the Caribbean Sea and the West Indies. Toxicon 56:698-710

Tindall DR, Miller DM, Tindall PM (1990) Toxicity of Ostreopsis lenticularis from the British and United States Virgin Islands. In: Granéli E, Sundström B, Edler L, Anderson DM (eds) Toxic marine phytoplankton. Elsevier, New York, NY, p 424-429

Tomas CR, Montresor M, Tosti E (1989) Nutrient and temperature effects on growth and sexual phases of four marine dinoflagellates. In: Okaichi T, Anderson DM, Nemoto T (eds) Red tides: biology, environmental science and toxicology. Elsevier, New York, NY, p 293-294

Totti C, Accoroni S, Cerino F, Cucchiari E, Romagnoli T (2010) Ostreopsis ovata bloom along the Conero Riviera 
(northern Adriatic Sea): relationships with environmental conditions and substrata. Harmful Algae 9:233-239

Underwood GJC, Boulcott M, Raines CA, Waldron K (2004) Environmental effects on exopolymer production by marine benthic diatoms: dynamics, changes in composition, and pathways of production. J Phycol 40:293-304

Valderama JC (1995) Methods of nutrient analysis. In: Hallegraeff GM, Anderson DM, Cembella AD (eds) Manual of harmful marine microalgae. IOC, Manuals and Guides No 33. UNESCO, Paris, p 251-268

Vanucci S, Guerrini F, Milandri A, Pistocchi R (2010) Effects of different levels of $\mathrm{N}$ - and P-deficiency on cell yield,

Editorial responsibility: Patricia Glibert, Cambridge, Maryland, USA okadaic acid, DTX-1, protein and carbohydrate dynamics in the benthic dinoflagellate Prorocentrum lima. Harmful Algae 9:590-599

Vila M, Garcés E, Masó M (2001) Potentially toxic epiphytic dinoflagellate assemblages on macroalgae in the NW Mediterranean. Aquat Microb Ecol 26:51-60

> Wolfstein K, Stal LJ (2002) Production of extracellular polymeric substances (EPS) by benthic diatoms: effect of irradiance and temperature. Mar Ecol Prog Ser 236:13-22

Yasumoto T, Seino N, Murakami Y, Murata M (1987) Toxins produced by benthic dinoflagellates. Biol Bull (Woods Hole) 172:128-131

Submitted: August 19, 2011; Accepted: January 13, 2012

Proofs received from author(s): February 20, 2012 